Vol 41 (2016) No 184 291-309

\title{
The Concept of 'knowledgization' for Creating Strategic Vision in Higher Education: A Case Study of Northern Cyprus
}

\author{
Tuğberk Kaya ${ }^{1}$, Mustafa Sağsan ${ }^{2}$
}

\begin{abstract}
Based on the concept of the knowledge economy, higher education institutions can be used as knowledge hubs in order to train knowledge workers. In addition the formation of knowledge hubs will be the foundations of the Knowledge Cities. Currently in North Cyprus, there is a lack of understanding Knowledge Cities, which are the fundamental building blocks of a knowledge-based economy. The model proposed in this paper argues that higher education institutions can bridge this gap by educating knowledge workers and becoming knowledge hubs in the context of 'knowledgization'.

In this research, a questionnaire was completed by 42 lecturers and 432 university students in order to test the concept of 'knowledgization'. Recommendations had been made based on the findings to enable the concept of 'knowledgization' such as investing in mobile applications, having user-friendly and up-todate websites. Tolerance for failure is also important for institutions where initiatives should be given to try new methods and to encourage innovation. It is expected that the results of the study will be useful for universities to create a strategic vision based on the concept of 'knowledgization' which includes Organizational Capacity, Information Technology Capacity and Knowledge Capacity for the Higher Education system.
\end{abstract}

Keywords

Keywords
Knowledgization
Knowledge workers
Knowledge hubs
Knowledge cities
Cyprus
Article Info
Received: 22.12.2015
Accepted: 03.04.2016
Online Published: 27.04.2016

DOI: 10.15390/EB.2016.6195

\section{Introduction}

"The term "knowledge-based economy" results from a fuller recognition of the role of knowledge and technology in economic growth" (OECD, 1996, p. 9). In response to the competitive economic environment, there has been a significant worldwide increase in knowledge-based economies over the last thirty years, where "knowledge, skills and innovation matter more and more for business success, particularly in the 'developed' world" (Williams, Turner, \& Jones, 2010, p. 12). Knowledge economies require knowledge based urban development (KBUD). Knowledge cities (where citizens can access to new communication technologies, knowledge-based goods and services) are essential parts of KBUD. Well-paid employment, growth for community's income, sustainable

\footnotetext{
${ }^{1}$ Near East University, Faculty of Economics and Administrative Sciences, North Cyprus, Via Mersin 10, Turkey tugberk.kaya@neu.edu.tr

${ }^{2}$ Near East University, Faculty of Economics and Administrative Sciences, North Cyprus, Via Mersin 10, Turkey mustafa.sagsan@neu.edu.tr
} 
economy by increasing capacity on technological innovations and better education services are some benefits of Knowledge Cities (KCs) (Ergazakis, Metaxiotis, \& Psarras, 2004). KCs have Knowledge Hubs (KHs) which are mediums for transferring both tacit to tacit and tacit to explicit knowledge. An increased number of KHs will form Knowledge Clusters, which is important as "knowledge clusters have the organizational capability to drive innovations and create new industries" (Evers, Gerke, \& Menkhoff, 2010, p. 683). These industries will require workers, which is called Knowledge Workers (KWs) in the knowledge city concept. Drucker $(1977$, p. 22) emphasized the importance of knowledge workers by stating "attract and hold the highest-producing knowledge workers by treating them and their knowledge as the organization's most valuable assets". The findings above show that the knowledge worker concept is not a new concept. On the other hand, Northern Cyprus's low Innovation Capacity ( $145^{\text {th }}$ out of $145^{\text {th }}$ countries) shows that there is a gap in the field of training and educating knowledge workers.

Globalized companies and developed countries spend significant amounts of budget on Research \& Development (R\&D) activities. In spite of this worldwide trend, a recent competitiveness report prepared by Cyprus Turkish Chamber of Industry indicates that North Cyprus ranked $114^{\text {th }}$ out of 145 countries. In this report, it also ranked 144 $4^{\text {th }}$ for Innovation Capacity, 145 th (last position) for $R \& D$ expenditure and $104^{\text {th }}$ for $R \& D$ cooperation between businesses and universities. Although these figures show the country's lack of strategic vision and relative backwardness, the country is actually ranked $17^{\text {th }}$ for student registration rate in higher education with $87 \%$ (Sertoğlu, Besim, \& Tanova, 2015). In North Cyprus, there are currently 13 registered universities with 75,000 students (YÖDAK, 2015). It means that higher education is one of the main economic drivers of the country. When the current situation and registration levels at the higher education institutions are considered, there seems to be an opportunity to design and apply strategic higher education policies and practices on the macro level.

Accordingly, training for Knowledge Workers (KW) becomes crucial, as they are the key players in knowledge economies as mentioned above. Northern Cyprus has low levels of primary and secondary industries (extracting raw materials and producing semi-finished or finished goods). This is understandable as small island economies are mainly triggered by the services sector, where education is one of the main factors (Boto \& Biasca, 2012). For example, universities in North Cyprus contributed $£ 437,580$ to the economy in 2014 (Yeniduzen, 2015). It is also estimated that UK universities contributed $£ 73$ billion to the gross domestic product between 2011 and 2012 (Kelly, McNicoll, \& White, 2015). Alumni of the world's top 100 universities have an impact on the global environment, while graduates from other universities also affect their local economy (Thomson Reuters, 2015). This clearly shows that graduates do have an impact on the local economy and therefore a well-planned higher education strategy is crucial to boost the economy and governance of the country. This can be achieved through the "knowledgization" concept. "Universities are increasingly being recognized as knowledge hubs, exercising a strong influence on the intellectual vitality of the city where they are embedded" (Martinez-Fernandez \& Sharpe, 2008, p. 48). Correspondingly, this study asserts that universities can be mediums to develop required human capital via the concept of "knowledgization". 


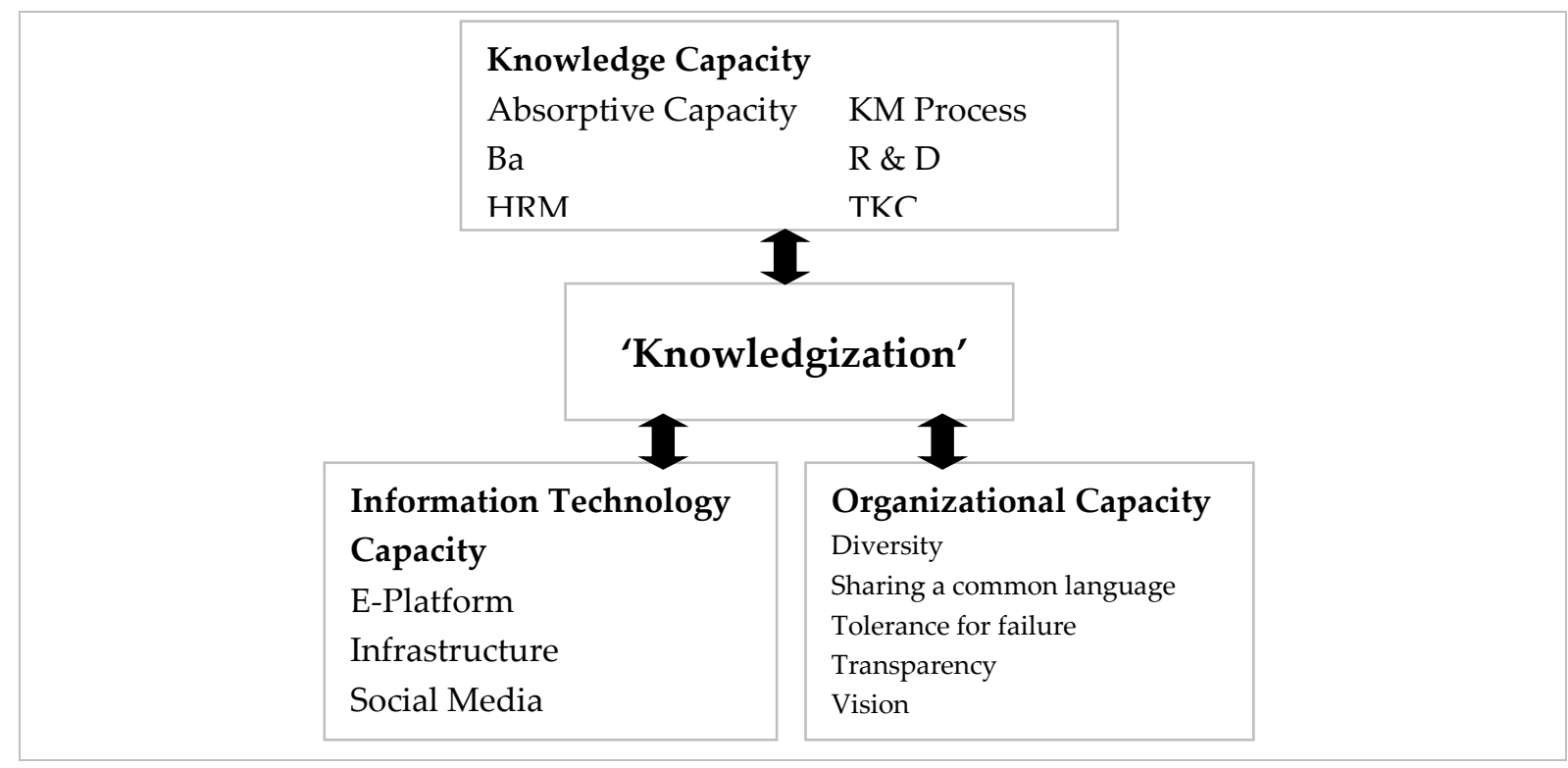

Figure 1: Representing the Research Model

Figure 1 demonstrates the fundamentals of the "knowledgization" concept. Each capacity will be explained in throughout the paper. The statements above highlight the importance of universities for creating Knowledge Clusters through training and education of the workforce (Yigitcanlar, O'Connor, \& Westerman, 2008). Educating knowledge workers require well develop organizational structure. For that reason, organizational capacity of institutions will be explained under the concept of "knowledgization".

\section{Organizational Capacity}

Organizational capacity includes the fundamental features that are important for improving the effectiveness of organizations. Organizational capacity includes diversity, sharing a common language, tolerance for failure, transparency and vision as it can be seen from the Figure 1. Shared language/jargon is crucial for tacit knowledge transfer (Joia \& Lemos, 2010) and improves the effectiveness of both the communication within a company and organizational learning. On the other hand, too much intensity and specialization of the language may "impede the incorporation of outside knowledge and result in the pathology of the not-invented-here (NIH) syndrome" (Cohen \& Levinthal, 1990, p. 133). Therefore, how the shared language is used is especially important for the continuity of the organizational culture. In addition, the presence of tolerance, transparency and a governance vision, accepting multiculturalism (diversity), and the availability of natural and quality built environments are also important indicators of KCs (Baum, Yigitcanlar, Horton, Velibeyoglu, \& Gleeson, 2006 as cited in Yigitcanlar, O'Connor, \& Westerman, 2008). Some benefits of KCs are 'accessibility, cutting edge technology, innovation, cultural facilities and services, quality education as well as world class economic opportunities' (Yigitcanlar, O'Connor, \& Westerman, 2008, p. 64). University administrations should adopt the 'knowledgization' strategy throughout their institutional development and organizational capacity. Cooperation with the local governance, especially with municipal and strategy teams, needs to be encouraged for the evolution of the concept. This will allow the 'knowledgization' concept to be spread city-wide; a milestone of becoming a knowledge city (Franz, 2008). Information Technology Capacity of the institutions indicates the potential or areas to develop for the concept of "knowledgization" which will be examined in next section. 


\section{Information Technology Capacity}

Information technology (IT) capacity includes features that improve an organization by using fundamental IT. It is expected that there will be 5.2 billion mobile users and more than 11 billion mobile devices by 2019. In addition, internet connection via Wi-Fi and mobile devices will account for $66 \%$ of total traffic (Cisco, 2015). These statistics show the trend towards mobile device usage and are an indication for educational institutions that they need to provide mobile platforms to enable student e-learning (United Nations, 2014). A recent study analyzed the usage of digital textbooks and the prediction of student course grades. It showed that improvements in this field can provide prewarnings if the students mark will be low (Junco \& Clem, 2015). Research of Junco and Clem (2015) shows the importance of e-Learning and finding effective ways to implement it will increase the quality of education, which will also boost IT Capacity.

Social media is one of the most used communication tools of the recent era (Fill, 2011; United Nations, 2014). Investing in social media applications will be effective to increase Tacit Knowledge Capacity (TKC), which is formed from tacit knowledge accumulation and tacit knowledge transfer, indicates amount of tacit knowledge acquired or transferred via an organization (Kaya \& Sağsan, 2015). For this reason, by considering the common usage and the effect on the TKC, social media will be used as a communication tool in the 'Knowledgization' concept in order to enable effective accumulation and transfer of tacit knowledge. The current social media usage of the students, lecturers and administration will be assessed to determine the current situation and usage habit and, based on this, new and effective techniques may be proposed to improve communication and TKC. Nevertheless, the sharing process or ability of the gatekeeper to transfer the external information will depend on the relevant knowledge and expertise (Cohen \& Levinthal, 1990). In addition, to Organizational and IT Capacities, Knowledge Capacity is also an important fundamental of the knowledgization concept.

\section{Knowledge Capacity}

Knowledge capacity includes dynamics that are fundamental for a knowledge organization. Absorptive Capacity, Ba, Human Resource Management (HRM), Knowledge Management (KM) Process, Research \& Development (R\&D) and Tacit Knowledge Capacity (TKC) will be examined in this section. Knowledge production and diffusion is crucial to gain long-term economic growth (Barro, 1991 as cited in OECD, 2001). Stable knowledge is not effective; knowledge and skills of the individuals must be used in order to enable contribution of knowledge as a means of economic growth (OECD, 2001). Therefore, administration is another important factor of the 'knowledgization' concept. Administration is important as knowledge itself will not provide competitive advantage unless it is managed effectively (Mellor et al., 2009).

In addition to knowledge management process, Absorptive Capacity is also an important factor that stimulates the explosion of relevant knowledge within an organization (Cohen \& Levinthal, 1990). "Clearly, the "absorptive capacity" of organizations varies substantially and this, in turn, affects their ability to produce innovations" (Cohen \& Levinthal, 1990, p.129). Cohen and Levinthal (1990) further stated that absorptive capacity is related with prior knowledge in an organization. The recognition, assimilation and application of new and external information are also crucial factors for facilitating innovation capabilities of businesses (Cohen \& Levinthal, 1990). 'Knowledge management, knowledge transfer, and innovation are the major research themes connected to absorptive capacity, together with other closely aligned concepts such as knowledge transfer and sharing, and knowledge creation and learning' (Mariano \& Walter 2015, p. 375).

These statements highlight the importance of the absorptive capacity. In addition there is a deficiency in the development and application of absorptive capacity in knowledge management (KM) and intellectual capital concepts (Wang \& Han, 2011; Mariano \& Walter, 2015). For that reason, an organization's absorptive capacity should also be assessed to evaluate its 'knowledgization' potential, as absorptive capacity will boost both innovation and KM (Mariano \& Walter, 2015). In addition to absorptive capacity, Tacit Knowledge Capacity (TKC) assesses tacit knowledge 
accumulation and tacit knowledge transfer within an organization (Kaya \& Sağsan, 2015). It is difficult to measure the impact of knowledge activities (Martinez-Fernandez \& Sharpe, 2008), as "the tacit knowledge concept is very difficult to explain as well the fact that it takes place at the abstract level of the mind" (Kaya \& Sağsan, 2015, p. 8). The extent of knowledge which will be created is important; however, more actions need to be taken in order make the knowledge accessible and accumulated (Martinez-Fernandez \& Sharpe, 2008), which make Absorptive and TKC crucial for improving the Knowledge Capacity of organizations.

Knowledge transfer is not an easy process as it requires time and space and related to this, the term 'Ba' has been defined as the medium of tacit knowledge transfer (Nonaka, Toyama, \& Konno, 2000). "Ba is an important concept for knowledge management. A knowledge cities model, in the absence of Ba, will be of a little value to its citizens" (Baqir \& Kathawala, 2004, p. 84). Specialized knowledge will determine the importance of $R \& D$. $R \& D$ is crucial for specialized areas when assimilation of external knowledge is easy and does not require expertise (Cohen \& Levinthal, 1990). While the importance of $R \& D$ is indicated, North Cyprus do not have high R\&D spending as mentioned above. "The higher the degree of complex knowledge, the better the management innovation performance" (Wang \& Han, 2011, p. 814). This indicates that institutions need to improve their knowledge pools, especially tacit knowledge capacity as tacit knowledge is the complex form of knowledge (Nonaka et al., 2000). Accessing external knowledge is important; however, absorptive capacity is decisive as to what extent the tacit knowledge will be absorbed. Therefore, absorptive capacity should be increased as the availability of external knowledge increases, as stated above (Wang \& Han, 2011).

The development of human capital is also an important factor for increasing knowledge capacity. (Van Winden, Berg, \& Pol, 2007). "A knowledge city is based on the availability and skill level of its human capital" (Ergazakis, Metaxiotis, Psarras, \& Askounis, 2006, p. 72). "Educational institutions influence talent generation within a KC" (Yigitcanlar, O'Connor, \& Westerman, 2008, p. 65). Human capital is important which is supported by the absorptive capacities of employees. Individual absorptive capacities will form the organization's overall absorptive capacity, thus technical training for employees will improve the absorptive capacity of organizations as a whole (Cohen \& Levinthal, 1990). Furthermore, strategies must be set in order to enable investment for the development of human capital (Ergazakis et al., 2006). "Learning capabilities involve the development of the capacity to assimilate existing knowledge, while problem-solving skills represent a capacity to create new knowledge" (Cohen \& Levinthal, 1990, p. 130). This statement indicates that the capabilities may be different; however, knowledge management is critical as some skills will be used for the assimilation of external knowledge and some will be used for innovation.

In addition to the development of human capital, the development of knowledge-based industries is also important as indicated by Van Winden et al. (2007). Martinez-Fernandez and Sharpe (2008) stated that universities are increasingly recognized as KHs where they are showing a significant influence on the intellectual vitality of the city where they are located. Providing effective environments for information exchange and networking will encourage the development of knowledge-based industries. Knowledge is important and it needs to be absorbed by the organization. Therefore, gatekeepers are important for the absorptive capacity of businesses and they can monitor the external environment in order to assimilate current trends throughout the organization. Circulation of the assimilated information is also important and the internal communication of subunits within the organization is important for the explosion of knowledge. Effective tracking, explosion and assimilation will result in cumulative learning (Cohen \& Levinthal, 1990), leading to continuous innovation. Hence, the 'knowledgization' concept will assess the gatekeepers of the organizations, their frequency of monitoring as well as actions they perform in order to enable smooth explosion and assimilation of the knowledge by employees. Gatekeepers will increase the amount of knowledge absorbed by the organization therefore chance of innovation. Innovative ways of urban planning are required in response to global competition and knowledge driven economies (Yigitcanlar 
\& Bulu, 2015). The development and progress of the Knowledge City strategy is dependent on the local government, mainly the municipalities. Therefore further strategies must be established and cooperation between universities and local government should be increased (Franz, 2008).

\section{Towards a conceptual model: 'knowledgization'}

From the literature analysis, it was found that indicators of the 'knowledgization' concept can be summarized under the title of Organizational Capacity, which includes: diversity; vision; tolerance for failure; sharing a common language and transparency (Yigitcanlar, Velibeyoglu, \& MartinezFernandez, 2008; Yigitcanlar \& Bulu, 2015); IT Capacity, which is formed up from e-Platform, Infrastructure and Social media; Knowledge Capacity, which includes the KM process (MartinezFernandez \& Sharpe, 2008; Mellor et al., 2009); Human Capital of the organization (Van Winden et al., 2007); Ba (Nonaka et al., 2000); Research \& Development; Absorptive Capacity (Cohen \& Levinthal, 1990); and the Tacit Knowledge Capacity (TKC) (Kaya \& Sağsan, 2015).

The Knowledge City $(\mathrm{KC})$ concept is perceived to be a viable, sustainable and vibrant method of urban development (Yigitcanlar \& Velibeyoglu, 2008). 'The KC concept embarks on a strategic mission to firmly encourage and nurture locally focused innovation, science and creativity within the context of an expanding knowledge economy and society' (Yigitcanlar, O'Connor, \& Westerman, 2008, p. 63). The concept of 'knowledgization' can be a road map for KCs formed up from Organizational Capacity, Information Technology (IT) Capacity and Knowledge Capacity. The 'knowledgization' concept includes: absorptive capacity, which is a key aspect of the learning and innovation of the firms conducted by Cohen and Levinthal (1990); 'Ba', which is the place and time for the knowledge transfer (Nonaka et al., 2000); assessment and evaluation of the relevant knowledge (generation, transmission and transfer of the relevant knowledge) as mentioned by MartinezFernandez and Sharpe (2008).

The 'knowledgization' concept aims to improve urban development, where three intellectual measures (generation, transmission and transfer) are used for the relevant knowledge. Relevant knowledge is the knowledge that improves a particular area of industry and therefore has significant importance (Martinez-Fernandez \& Sharpe, 2008). Coalescence of relevant knowledge with other indications of the 'knowledgization' concept such as absorptive capacity, human capital, diversity, transparency and vision can be a key indicator to improve a universities' knowledge generation potential, which will have a direct impact on the potential of the city if the knowledge management process is effective. Innovative methods need to be used by universities in order to transfer knowledge and to enable efficient accumulation by the community, private and public institutions (Martinez-Fernandez \& Sharpe, 2008). Applying the 'knowledgization' model will be a strategic advantage for institutions and it will be a milestone for becoming a Knowledge City as "only cities with knowledge-producing scientific institutions (universities, research institutes) will have a chance to evolve into a knowledge city" (Franz, 2008, p. 105). The 'knowledgization' concept will assess the current structure, and prepares the institutions to become a $\mathrm{KC}$, which is a fundamental aspect of knowledge economies (Yigitcanlar \& Bulu, 2015). 


\section{Method}

\section{Research Design}

This is a case study that aims to analyze the 'knowledgization' potential of Higher Education Institutions in Nicosia. The city has been selected as a case study for two reasons. Firstly, this study can be used as benchmark as Nicosia is the only divided capital in the world. Therefore, having a study in North Nicosia will enable to carry out research in South in upcoming researches. In addition, successful implementation of the model in this city will result to use the same model in other cities so waterfall expansion can be made. The 'knowledgization' concept has the dependent variable of Knowledge Capacity and has independent variables of Information Technology and Organizational Capacity as demonstrated by Figure 1 .

\section{Research Question}

What is the current capacity of the Near East University to apply 'knowledgization' concept?

\section{Research Aims}

- To examine the fundamentals of the 'knowledgization' concept

- To propose a guideline for the 'knowledgization' concept.

\section{Participants}

No matter how effective the transfer of knowledge is, it may not be accumulated if the absorptive capacity of the organization is not developed (Cohen \& Levinthal, 1990). In the same manner, the transfer of knowledge to reach the 'knowledgization' concept may not be effective if it is perceived differently among students, lecturers and the administration. A clear vision needs to be established and understood in the same manner by all stakeholders. For that reason, a 'knowledgization' questionnaire was completed by three different groups (students, lecturers and the administration) from the Faculty of Economics and Administrative Sciences and the Faculty of Architecture at Near East University, in order to analyze the current situation from a wider perspective.

It has been outlined that the profile of executives has shifted from specialist education to general education, mainly within the fields of business and management (Thomson Reuters, 2015). For that reason, the Faculty of Economics and Administrative Sciences was selected as this faculty focuses on managerial education. Primary research was also conducted at the Faculty of Architecture, as members of this faculty will be fundamental for the design of future knowledge cities. A total of 42 university lecturers and 434 university students participated in the research. $54 \%$ of them were male whereas $46 \%$ of them were female. The age range was $25-60$ years for university lecturers and 18-40 for students.

\section{Data Analysis}

Primary Research was conducted on the participants, who were 42 university lecturers and 434 university students. Participants voluntarily participated in the research during fall academic term (September to November 2015). 1 to 5 Likert scale was used for the questionnaire which included 58 positive statements where the participants responded by selecting the most relevant answer for them (Strongly Disagree, Disagree, Neutral, Agree and Strongly Agree). The collected responses were coded and calculated by using IBM SPSS Statistics 20 program. Reliability and validity: Cronbach's Alpha value was 0.938 . 


\section{Results}

\section{Formulas for Regression Models}

Absorptive Capacity $=1.429+0.232^{*}$ Infrastructure $+0.221^{*}$ E-Platform

Absorptive Capacity $=0.573+0.136^{*}$ Diversity $+0.150^{*}$ Tolerance for Failure + $0.255^{*}$ Transparency

$\mathbf{B a}=1.224+0.286^{*}$ E-Platform $+0.246^{*}$ Infrastructure $+0.164^{*}$ Social Media

$\mathbf{B a}=1.140+0.234^{*}$ Tolerance for Failure $+0.289^{*}$ Transparency $+0.156^{*}$ Vision

HRM $=0.949+0.129^{*}$ Diversity $+0.300^{*}$ Transparency $+0.133^{*}$ Vision

HRM $=1.421+0.253^{*}$ E-Platform $+0.241^{*}$ Infrastructure

KM Process $=1.722+0.241^{*}$ E-Platform $+0.176^{*}$ Infrastructure

KM Process $=1.402+0.113^{*}$ Diversity $+0.216^{*}$ Tolerance for Failure $+0.178^{*}$ Transparency

$\mathbf{R} \& \mathbf{D}=0.947+0.126^{*}$ Sharing a common language $+0.238^{*}$ Tolerance for Failure+ $0.195^{*}$ Transparency

$\mathbf{R} \& \mathbf{D}=1.340+0.223$ *E-Platform +0.176 * Infrastructure +0.112 * Social Media

TKC $=1.454+0.267 *$ E-Platform $+0.191 *$ Infrastructure

TKC $=0.838+0.101 *$ Diversity $+0.212 *$ Tolerance for Failure $+0.250 *$ Transparency +0.141 * Vision

\section{Regression Models}

According to the correlations of the primary data findings the following regression models had been designed. All models are significant by the multiple linear regression model at the level of $\mathrm{p}$ $<0.01$;

Table 1. Representing Regression Models for the Absorptive Capacity

\begin{tabular}{|c|c|c|c|c|c|}
\hline $\begin{array}{l}\text { Dependent } \\
\text { Variable }\end{array}$ & $\begin{array}{l}\text { Independent } \\
\text { Variables }\end{array}$ & $\begin{array}{l}\text { Multiple Linear } \\
\text { Regression }\end{array}$ & $\begin{array}{l}\text { Adjusted } \\
\text { R Square }\end{array}$ & Coefficients & $\begin{array}{l}\text { Standardized } \\
\text { Coefficients (Beta) }\end{array}$ \\
\hline $\begin{array}{l}\text { Model } 1 . \\
\text { Absorptive } \\
\text { Capacity }\end{array}$ & $\begin{array}{l}\text { IT Capacity } \\
\text { (Infrastructure, E- } \\
\text { Platform, Social } \\
\text { Media) }\end{array}$ & $.000^{\mathrm{b}}$ & .213 & Infrastructure (.000) & .282 \\
\hline $\begin{array}{l}\text { Model } 2 . \\
\text { Absorptive } \\
\text { Capacity }\end{array}$ & $\begin{array}{l}\text { Organizational } \\
\text { Capacity } \\
\text { (Diversity, Sharing } \\
\text { a common } \\
\text { language, } \\
\text { Tolerance for } \\
\text { failure, } \\
\text { Transparency, } \\
\text { Vision) }\end{array}$ & $.000^{\mathrm{b}}$ & .310 & $\begin{array}{l}\text { Diversity }(.002) \\
\text { Tolerance for } \\
\text { Failure }(.003) \\
\text { Sharing a common } \\
\text { language }(.003)\end{array}$ & $\begin{array}{l}.140 \\
.139\end{array}$ \\
\hline
\end{tabular}




\section{Model 1}

The effect of 'knowledgization' was analyzed to see if there is a relationship between the dependent variable (Absorptive Capacity) and the independent variable IT Capacity (E-Platform, Infrastructure and Social Media). Infrastructure will be affected by 0.282 and E-Platform will be affected by 0.236 when the Absorptive Capacity is upgraded by 1 unit.

\section{Model 2}

The Effect of 'knowledgization' was analyzed to see if there is a relationship between the dependent variable (Absorptive Capacity) and the independent variable Organizational Capacity (Diversity, Sharing a common language, Tolerance for failure, Transparency, Vision). Diversity will be affected by 0.140 , Tolerance for Failure will be affected by 0.139 and Transparency will be affected by 0.265 when the Absorptive Capacity is upgraded by 1 unit.

Table 2. Representing Regression Models for the Ba

\begin{tabular}{|c|c|c|c|c|c|}
\hline $\begin{array}{l}\text { Dependent } \\
\text { Variable } \\
\end{array}$ & $\begin{array}{l}\text { Independent } \\
\text { Variables }\end{array}$ & $\begin{array}{l}\text { Multiple Linear } \\
\text { Regression }\end{array}$ & $\begin{array}{l}\text { Adjusted } \\
\text { R Square }\end{array}$ & Coefficients & $\begin{array}{l}\text { Standardized } \\
\text { Coefficients (Beta) }\end{array}$ \\
\hline \multirow[t]{3}{*}{ Model 3. Ba } & IT Capacity & $.000^{\mathrm{b}}$ & .317 & Infrastructure (.000) & .276 \\
\hline & $\begin{array}{l}\text { (Infrastructure, } \\
\text { E-Platform, }\end{array}$ & & & E-Platform (.000) & .283 \\
\hline & Social Media) & & & Social Media (.001) & .145 \\
\hline \multirow[t]{3}{*}{ Model 4. Ba } & $\begin{array}{l}\text { Organizational } \\
\text { Capacity } \\
\text { (Diversity, }\end{array}$ & $.000^{\mathrm{b}}$ & .285 & $\begin{array}{l}\text { Tolerance for } \\
\text { failure }(.000)\end{array}$ & .201 \\
\hline & $\begin{array}{l}\text { Sharing a } \\
\text { common }\end{array}$ & & & Transparency (.000) & .277 \\
\hline & $\begin{array}{l}\text { language, } \\
\text { Tolerance for } \\
\text { failure, } \\
\text { Transparency, } \\
\text { Vision) }\end{array}$ & & & Vision (.012) & .123 \\
\hline
\end{tabular}

\section{Model 3}

The Effect of 'knowledgization' was analyzed to see if there is a relationship between the dependent variable $(\mathrm{Ba})$ and the independent variable IT Capacity (E-Platform, Infrastructure and Social Media). Infrastructure will be affected by 0.276 , E-Platform will be affected by 0.283 and Social Media will be affected by 0.145 when the Ba is upgraded by 1 unit.

\section{Model 4}

The Effect of 'knowledgization' was analyzed to see if there is a relationship between the dependent variable $(\mathrm{Ba})$ and the independent variable Organizational Capacity (Diversity, Sharing a common language, Tolerance for failure, Transparency, Vision). Tolerance for Failure will be affected by 0.201 , Transparency will be affected by 0.277 and Vision will be affected by 0.123 when the Ba is upgraded by 1 unit. 
Table 3. Representing Regression Models for HRM

\begin{tabular}{llllll}
\hline $\begin{array}{l}\text { Dependent } \\
\text { Variable }\end{array}$ & $\begin{array}{l}\text { Independent } \\
\text { Variables }\end{array}$ & $\begin{array}{l}\text { Multiple Linear } \\
\text { Regression }\end{array}$ & $\begin{array}{l}\text { Adjusted } \\
\text { R Square }\end{array}$ & Coefficients & $\begin{array}{l}\text { Standardized } \\
\text { Coefficients (Beta) }\end{array}$ \\
\hline $\begin{array}{l}\text { Model 5. } \\
\text { HRM }\end{array}$ & $\begin{array}{l}\text { IT Capacity } \\
\text { (Infrastructure, }\end{array}$ & $.000^{\mathrm{b}}$ & .304 & Infrastructure (.000) & .313 \\
& $\begin{array}{l}\text { E-Platform, } \\
\text { Model 6. }\end{array}$ & & & E-Platform (.000) & .291 \\
HRM & $\begin{array}{l}\text { Organizational Media) } \\
\text { Capacity(Diversity, } \\
\text { Sharing a common } \\
\text { language, }\end{array}$ & $.000^{\mathrm{b}}$ & .337 & Diversity (.001) & .142 \\
& $\begin{array}{l}\text { Tolerance for } \\
\text { failure, } \\
\text { Transparency, }\end{array}$ & & Transparency (.000) & .334 \\
& & & Vision (.010) & .122 \\
& & & & \\
\end{tabular}

\section{Model 5}

The Effect of 'knowledgization' was analyzed to see if there is a relationship between the dependent variable (HRM) and the independent variable IT Capacity (E-Platform, Infrastructure and Social Media). Infrastructure will be affected by 0.313 and E-Platform will be affected by 0.291 when the HRM is upgraded by 1 unit.

\section{Model 6}

The Effect of 'knowledgization' was analyzed to see if there is a relationship between the dependent variable (HRM) and the independent variable Organizational Capacity (Diversity, Sharing a common language, Tolerance for failure, Transparency, Vision). Diversity will be affected by 0.142 , Transparency will be affected by 0.334 and Vision will be affected by 0.122 when the HRM is upgraded by 1 unit.

Table 4. Representing Regression Models for the KM Process

\begin{tabular}{llllll}
\hline $\begin{array}{l}\text { Dependent } \\
\text { Variable }\end{array}$ & $\begin{array}{l}\text { Independent } \\
\text { Variables }\end{array}$ & $\begin{array}{l}\text { Multiple Linear } \\
\text { Regression }\end{array}$ & $\begin{array}{l}\text { Adjusted } \\
\text { R Square }\end{array}$ & Coefficients & $\begin{array}{l}\text { Standardized } \\
\text { Coefficients (Beta) }\end{array}$ \\
\hline $\begin{array}{l}\text { Model 7. } \\
\text { KM }\end{array}$ & $\begin{array}{l}\text { IT Capacity } \\
\text { (Infrastructure, }\end{array}$ & $.000^{\mathrm{b}}$ & .260 & Infrastructure (.000) & .250 \\
Process & $\begin{array}{l}\text { E-Platform, } \\
\text { Social Media) }\end{array}$ & & & E-Platform (.000) & .300 \\
Model 8. & $\begin{array}{l}\text { Organizational } \\
\text { KM }\end{array}$ & $.000^{\mathrm{b}}$ & .267 & Diversity (.003) & .136 \\
Process & $\begin{array}{l}\text { Sharing a common } \\
\text { language, } \\
\text { Tolerance for } \\
\text { failure, } \\
\text { Transparency, }\end{array}$ & & Transparency (.000) & .215 \\
& & & Tolerance for & .234 \\
& & & failure $(.000)$ & \\
& & & & \\
\hline
\end{tabular}




\section{Model 7}

The Effect of 'knowledgization' was analyzed to see if there is a relationship between the dependent variable (KM Process) and the independent variable IT Capacity (E-Platform, Infrastructure and Social Media). Infrastructure will be affected by 0.250 and E-Platform will be affected by 0.300 when the KM Process is upgraded by 1 unit.

\section{Model 8}

The Effect of 'knowledgization' was analyzed to see if there is a relationship between the dependent variable (KM Process) and the independent variable Organizational Capacity (Diversity, Sharing a common language, Tolerance for failure, Transparency, Vision). Diversity will be affected by 0.136, Transparency will be affected by 0.215 and Tolerance for failure will be affected by 0.234 when the KM Process is upgraded by 1 unit.

Table 5. Representing Regression Models for the R\&D

\begin{tabular}{|c|c|c|c|c|c|}
\hline $\begin{array}{l}\text { Dependent } \\
\text { Variable }\end{array}$ & $\begin{array}{l}\text { Independent } \\
\text { Variables }\end{array}$ & $\begin{array}{l}\text { Multiple Linear } \\
\text { Regression }\end{array}$ & $\begin{array}{l}\text { Adjusted } \\
\text { R Square }\end{array}$ & Coefficients & $\begin{array}{l}\text { Standardized } \\
\text { Coefficients (Beta) }\end{array}$ \\
\hline \multirow{3}{*}{$\begin{array}{l}\text { Model } 9 . \\
\text { R\&D }\end{array}$} & IT Capacity & $.000^{\mathrm{b}}$ & .208 & Infrastructure (.000) & .218 \\
\hline & $\begin{array}{l}\text { (Infrastructure, } \\
\text { E-Platform, } \\
\text { Social Media) }\end{array}$ & & & E-Platform (.000) & .244 \\
\hline & & & & Social Media (.020) & .109 \\
\hline \multirow[t]{3}{*}{$\begin{array}{l}\text { Model } 10 . \\
\text { R\&D }\end{array}$} & $\begin{array}{l}\text { Organizational } \\
\text { Capacity } \\
\text { (Diversity, }\end{array}$ & $.000^{\mathrm{b}}$ & .244 & $\begin{array}{l}\text { Sharing a common } \\
\text { language }(.007)\end{array}$ & .122 \\
\hline & $\begin{array}{l}\text { Sharing a common } \\
\text { language, } \\
\text { Tolerance for }\end{array}$ & & & $\begin{array}{l}\text { Tolerance for failure } \\
(.000)\end{array}$ & .226 \\
\hline & $\begin{array}{l}\text { failure, } \\
\text { Transparency, } \\
\text { Vision) }\end{array}$ & & & Transparency (.000) & .207 \\
\hline
\end{tabular}

\section{Model 9}

The Effect of 'knowledgization' was analyzed to see if there is a relationship between the dependent variable $(R \& D)$ and the independent variable IT Capacity (E-Platform, Infrastructure and Social Media). Infrastructure will be affected by 0.218 , E-Platform will be affected by 0.244 and Social Media will be affected by 0.109 when the R\&D is upgraded by 1 unit.

\section{Model 10}

The Effect of 'knowledgization' was analyzed to see if there is a relationship between the dependent variable (R\&D) and the independent variable Organizational Capacity (Diversity, Sharing a common language, Tolerance for failure, Transparency, Vision). Sharing a common language will be affected by 0.122 , Transparency will be affected by 0.207 and Tolerance for failure will be affected by 0.226 when the R\&D is upgraded by 1 unit. 
Table 6. Representing Regression Models for the TKC

\begin{tabular}{|c|c|c|c|c|c|}
\hline $\begin{array}{l}\text { Dependent } \\
\text { Variable }\end{array}$ & $\begin{array}{l}\text { Independent } \\
\text { Variables }\end{array}$ & $\begin{array}{l}\text { Multiple Linear } \\
\text { Regression }\end{array}$ & $\begin{array}{l}\text { Adjusted } \\
\text { R Square }\end{array}$ & Coefficients & $\begin{array}{l}\text { Standardized } \\
\text { Coefficients (Beta) }\end{array}$ \\
\hline \multirow[t]{2}{*}{$\begin{array}{l}\text { Model } 11 . \\
\text { TKC }\end{array}$} & $\begin{array}{l}\text { IT Capacity } \\
\text { (Infrastructure, }\end{array}$ & $.000^{\mathrm{b}}$ & .222 & Infrastructure $(.000)$ & .228 \\
\hline & $\begin{array}{l}\text { E-Platform, } \\
\text { Social Media) }\end{array}$ & & & E-Platform $(.000)$ & .282 \\
\hline \multirow[t]{4}{*}{$\begin{array}{l}\text { Model } 12 . \\
\text { TKC }\end{array}$} & $\begin{array}{l}\text { Organizational } \\
\text { Capacity }\end{array}$ & $.000^{\mathrm{b}}$ & .291 & Diversity (.024) & .103 \\
\hline & $\begin{array}{l}\text { (Diversity, } \\
\text { Sharing a common }\end{array}$ & & & Transparency (.000) & .255 \\
\hline & $\begin{array}{l}\text { language, } \\
\text { Tolerance for } \\
\text { failure, }\end{array}$ & & & $\begin{array}{l}\text { Tolerance for failure } \\
(.000)\end{array}$ & .194 \\
\hline & $\begin{array}{l}\text { Transparency, } \\
\text { Vision) }\end{array}$ & & & Vision (.015) & .119 \\
\hline
\end{tabular}

\section{Model 11}

The Effect of 'knowledgization' was analyzed to see if there is a relationship between the dependent variable (TKC) and the independent variable IT Capacity (E-Platform, Infrastructure and Social Media). Infrastructure will be affected by 0.228 and E-Platform will be affected by 0.282 when the TKC is upgraded by 1 unit.

\section{Model 12}

The Effect of 'knowledgization' was analyzed to see if there is a relationship between the dependent variable (TKC) and the independent variable Organizational Capacity (Diversity, Sharing a common language, Tolerance for failure, Transparency, Vision). Diversity will be affected by 0.103 , Transparency will be affected by 0.255 , Tolerance for failure will be affected by 0.194 and Vision will be affected by 0.119 when the TKC is upgraded by 1 unit.

\section{Discussion and Conclusion}

In the current highly competitive economic environment, knowledge cities are strategically advantageous for the economies of countries especially which have island economy (Çavuşoğlu \& Sağsan, 2011). The availability of universities provides huge potential for these cities. If the transformation can be planned and implemented, a university's Knowledge Capacity can be improved and they will be converted into Knowledge Hubs. Having a variety of Knowledge Hubs will improve the 'knowledgization' process, the first step of becoming a Knowledge City (KC). Transformation of KC's will be a strategic advantage for the Cypriot economy and education system. Applying 'knowledgization' concept within the strategic vision for Northern Cyprus will provide opportunities to improve educational quality as well as to meet economic expectations and foster R\&D activities, which will improve business activities. According to the regression models, it is clearly seen that knowledge capacity of an organization has been affected by IT Capacity and Organizational Capacity based on some parameters such as Absorptive Capacity, Ba, HRM, KM process, R\&D and TKC.

Having a common language/jargon is important as suggested in the literature, as primary research findings indicate that sharing a common language is an effective way to increase the Absorptive Capacity of institutions. Diversity, being tolerant for failure and transparency are also important fundamentals of Organizational Capacity, which affects Absorptive Capacity. Components of IT Capacity (Infrastructure and E-Platform) also have a positive impact on the absorptive capacity of an organization. As mentioned in the literature, $\mathrm{Ba}$ is the place (physical/virtual/mental) and time where knowledge is created (Nonaka et al., 2000). The management vision, their transparency and 
tolerance for failure is important to improve Ba as well as to develop Infrastructure, E-Platforms and for the effective use of Social Media. In spite of the fact that is mentioned that social media has on impact on TKC (Kaya \& Sağsan, 2015), primary research findings did not find any relationship. On the other hand, Infrastructure and e-Platform are important to improve TKC as well as management vision, transparency, diversity and tolerance for failure.

Government expenditure for $R \& D$ is an effective method for the transformation of a region into a knowledge economy (Martinez-Fernandez \& Sharpe, 2008). The North Cyprus Government's current budget for research and improving higher education could not be found because of high nepotism. This shows a lack of vision on the macro level and urgent action needs to be taken to improve the current situation and to encourage $R \& D$ activities. Investing on $R \& D$ activities will be the foundation of the knowledge economy. Furthermore, funding needs to be provided for national and international conferences and research networks, where researchers will have the chance to present their work as well as to gain new state-of-the art knowledge from other researchers in their field. They will diffuse their observations and keep their transmitted knowledge active (Martinez-Fernandez \& Sharpe, 2008; Yigitcanlar \& Bulu, 2015). In addition, primary research findings indicate that components of IT Capacity (Infrastructure, E-Platform and Social Media) have a positive impact on an institution's R\&D capacity. For this reason, possible considerations to improve these aspects are advised for the universities. The findings further highlight that being transparent, sharing a common language and having a tolerance for failure also effect $R \& D$ institutions positively.

A 'Knowledge base' is crucial, which 'comprises the universities, polytechnics and other public and private R\&D activities in the urban region (knowledge infrastructure), as well as the educational level of the population' (Van Winden et al., 2007, p. 529). The Knowledge Base structure of North Cyprus appears to be rich as there are 13 registered universities and more applications to establish new universities are pending (YÖDAK, 2015). Furthermore, 87.3\% of high school graduates register for higher education (Sertoğlu et al., 2015). On the other hand, R\&D activities are not dominant, highlighted by the fact that North Cyprus ranked $104^{\text {th }}$ for R\&D cooperation between universities and the private sector. This shows that macro level policies should be developed in order to encourage cooperation on R\&D activities between universities and the private sector. The education structure must be focused on research-based progress. As mentioned above, there are university opening requests at the Ministry of Education. Minimum research ratios for universities must be set $(1$ research project per 10 students), which will trigger an increased number of R\&D activities. The Ministry of Education currently does not provide any funding for encouragement. For that reason, it can be advised that the Ministry allocate some of its budget for R\&D funding. Businesses that carry out their own R\&D activities have better absorptive capacities (Cohen \& Levinthal, 1990). It could therefore be said that increasing partnerships and the number of R\&D activities between universities and the private sector will increase their absorptive capacity and therefore innovation capabilities.

"How well an urban region responds to the challenge of the knowledge economy depends on how well actors exploit new knowledge in the form of new products or process innovations and utilize their intangible assets, such as skills and creativity" (Konstadakopulos, 2003 as cited in Yigitcanlar \& Lönnqvist 2013, p. 358). Statement also highlighted that collaboration between businesses and universities needs to be encouraged, which will increase knowledge worker availability as well as the standing of the universities in terms of R\&D and will have a positive impact on Knowledge Based Urban Development (Yigitcanlar, O'Connor, \& Westerman, 2008). Tax allowances or benefits could be provided to private firms to encourage cooperation. As the "development of a domestic market for knowledge-based products is a first step for an innovation economy to emerge" (Yigitcanlar \& Bulu, 2015, p. 201), universities should be encouraged to develop product innovation by increasing their R\&D activities. Strategies must be set together on a macro-level to encourage R\&D activities, not only at the university where research is carried out, but also in other universities. This can increase the amount of knowledge that will be produced and consequently its absorption by businesses and government. 
Knowledge can either be created within a region or it can be carried by migration (Hilpert, 2006). The diversity of people, businesses and cultures in cities constitutes a fertile ground for new ideas and innovations (Van Winden et al., 2007, p. 100). Although these statements highlight that diversity is an important factor to increase the knowledge capacity, the statistics in Northern Cyprus indicate that there is a lack of diversity and this can be rectified by universities. Primary research findings also indicate that diversity has a positive effect on the Absorptive Capacity, HRM, KM Process and TKC of organizations. 'Balance and integration is important for an effective long-term KBUD sustainability (Yigitcanlar, 2014) therefore, macro-level implementation of 'knowledgization' policies is essential.

Human capital is one of the important aspects of the 'knowledgization' concept (Van Winden et al., 2007) where diversity, transparency and vision have positive influence as well as the Infrastructure and e-Platform of the institutions. "A diverse background provides a more robust basis for learning because it increases the prospect that incoming information will relate to what is already known" (Cohen \& Levinthal, 1990, p. 131). Attaining human capital from different countries is important as the diversity will increase ideas and opinions about a subject and also will prevent the "not-invented-here" syndrome (Cohen \& Levinthal, 1990), which may prevent creativity. For that reason, digital marketing of both the institutions and Nicosia (the capital) needs to be developed in order to increase awareness of the city, which will help to attract students and researchers. In addition to diversity, vision and transparency also have a positive impact on HRM.

The Infrastructure of the area is important for increasing Knowledge Capacity as it is found that both E-Platforms and Infrastructure have a positive impact on all fundamental aspects of the Knowledge Capacity variable (Absorptive Capacity, Ba, HRM, KM Process, R\&D and TKC). Therefore, it could be stated that the current structure of the university and related accommodations needs to be improved, as well-equipped and comfortable housing could be more attractive for students/researchers (Franz, 2008). "Attracting new firms and scientific institutions" (Franz, 2008, p. 107 ) is a policy measure to improve urban economic development. Foreign investments will be helpful to create a more diversified workforce, improve economic transactions and improve knowledge produced within the region. Currently, tax allowances are provided for new start-ups (education wise and commercial). It is advised to maintain the same policy and to improve benefits while also supporting local businesses and institutions. In addition, technological firms such as cyber parks or techno cities can be established in Nicosia city by collaborating with the universities. Required legislations can speed up improving IT Capacity of universities.

In order to increase the effectiveness of local industry and the development of a city, external knowledge is required (Martinez-Fernandez \& Sharpe, 2008). Networking activities need to be organized in order to provide a medium to increase knowledge transfer between universities and the private sector. Partnership in the fields of knowledge and innovation within firms and universities will have a significant impact on competitiveness and will improve the intellectual vitality of the region (Martinez-Fernandez \& Sharpe, 2008). The KM Process is affected by Infrastructure and EPlatform as well as diversity, tolerance for failure and transparency. Networking will increase diversity, as it will enable universities to expand their connections. Governments sometimes may not be able to analyze the required strategies. For this reason, applying a bottom-up approach is important with the cooperation of local decision makers, in order to satisfy the demands of the city (Perry, 2008). Forming a city initiative would enable effective demand analysis of the city and this initiative can coordinate the relationship and dialogue between the universities, private firms, research institutions and local government. Being transparent and having a clear vision is important in this case as it will also increase the Ba and HRM of the universities. As every new attempt to change will meet some resistance due to supporters of the existing status quo and ambiguity of the future (Balogun \& Hailey, 2008). A well prepared change management and implementation plan needs to be prepared through joint contribution of the initiative stakeholders (universities, private firms and local 
government). The aims of the initiative should also be circulated to improve public relations and marketing activities as well as satisfy the needs of the demand analysis.

The Ministry of Education should organize an annual academic meeting where researchers from different universities and different cities or even countries will participate according to their field of study. New and extensive knowledge could be accumulated in these meetings where workshops could be facilitated in order to set short- and long-term higher education strategies. Furthermore, the requirements of the public and private sectors can be determined and actions to fulfil these requirements can be taken. This will enable the 'knowledgization' concept to be established within the city and for the concept to be spread to other cities if managed effectively. In addition, the Ministry of Education and Education Faculties should establish a relevant curriculum for effective application of the 'knowledgization' concept. There is a newly established union of universities. This organization needs to lobby government institutions in order to increase the communication and partnership (consultation, collaboration) between the government and universities. In addition, the union and government need to set an agenda in response to demand analysis; the courses provided need to be modified according to the skills gap. This will effectively match the knowledge workers (university graduates) with the private firms and public institutions, as well as increase the cooperation. Higher Education Planning, Evaluation, Accreditation and Coordination Council can have lean/adhocratic structure and needs to be more institutionalized where education related non-governmental organizations, union of universities representatives and independent education specialist need to be involved in the decision making process to make the council more adhocracy.

Hubs need to be created, which will include representatives from government institutions, the private sector and research centers. These will increase direct communication between the participants and it will be easier to determine and transfer the required knowledge by means of consultancy or seminars. Sharing a common language, having the same vision of the future and tolerance for failure will improve organizational communication, absorptive capacity and therefore the 'knowledgization' effect. University administration should provide a common language and clearly define short- and long-term targets, as well as the mission and vision of the country. Publications make the knowledge explicit whereby absorption and assimilation becomes easier (Nonaka et al., 2000). The Faculty of Economics and Administrative Sciences currently has a scientific journal, which is published twice a year. It would be beneficial if this journal were circulated among industry professionals and government authorities to increase their knowledge within the field. Furthermore, the number of journals and cooperation between the private sector and universities needs to be encouraged where common studies can find and propose solutions and innovative methods for the sector.

In Germany, the majority of the universities are controlled by the state and state intervention can have an impact on the efficiency of universities as well as prevent/slow down implementation of strategies, such as becoming a knowledge city (Franz, 2008). This situation is not valid in North Cyprus as the Ministry of Education and Higher Education Planning, Evaluation, Accreditation and Coordination Council do have some regulations; however, there are only two state-owned universities and the rest are privately owned. For this reason, it is expected that implementation of the 'knowledgization' concept will be easier and faster in privately owned universities as there would be fewer regulations. In North Cyprus, there are schemes that support employment of local graduates (Çalışma ve Sosyal Güvenlik Bakanlığı, 2015). Therefore it is advised to maintain the current schemes. Demand analysis also needs to be made to identify the skills gap and to set/modify the schemes according to the required human capital.

"Frequently a city's decision to practice a knowledge city strategy is linked to a re-alignment of its local economic development policy" (Franz, 2008, p. 106). Therefore, future benefits and advantages need to be clearly presented and the 'knowledgization' concept should be embedded in the future development strategy for higher education and government institutions. Assimilation of the 'knowledgization' vision by the Higher Education Planning, Evaluation, Accreditation and Coordination Council will improve the spread of the 'knowledgization' process. Therefore, policies to 
enable the implementation of 'knowledgization' need to be developed and the infrastructure also needs to be improved, as the concept will prepare the institutions to be the part of knowledge cities, a fundamental aspect of knowledge economies. To conclude, it should be stated that governments and other authorities need to set a vision for 'knowledgization'; having a well thought out, objective driven agenda will enable them to follow the steps to achieve 'knowledgization'.

Universities have the capacity for acquiring and applying the required knowledge for effective revitalization of the city; however, there is no model that is currently available for this purpose (Martinez-Fernandez \& Sharpe, 2008). For this reason, a Road Map for 'Knowledgization' (see in Table 7) has been created in order to contribute to the available literature. Educational institutions and local/regional governments can use this road map as a framework to increase the knowledge capacity of their cities. The proposed recommendations will improve the knowledge capacity of universities. It will be beneficial to carry out this research in other cities and universities to enable a country-wide assessment and evaluation. Having a guideline will be helpful to convert universities into Knowledge Hubs via the concept of 'knowledgization', which will be a strategic advantage for higher education institutions.

Table 7. Road Map for 'knowledgization'

\section{Improving Knowledge Capacity}

Absorptive and Tacit Knowledge Capacity

- Providing networking activities for private companies and public government representatives in order to exploit new knowledge

- Strategies must be set on the macro level, where the Ministry of Education and universities should provide funding to encourage R\&D activities throughout the projects.

Knowledge Management Process

- Academic publications should be circulated among industry professionals and government representatives to increase the KM process for citizens and the region where Cyber parks and techno cities will enable improving infrastructure of the universities and the region.

- Annual academic meetings should be organized for the accumulation of new and quality knowledge, to set short and long-term goals and to meet the needs of the public and private sectors

- The Ministry of Education and Education Faculties should prepare a curriculum that will enable effective application of the "Knowledgization" concept

Improving IT Capacity

E-Platform

- Universities should invest in mobile applications. University websites and student portals should be user friendly, have rich and up-to-date content and provide an effective medium for communication

Infrastructure

- Universities should provide Wi-Fi connectivity at the most effective rate. They should invest in modern IT infrastructure (increase the number of computer labs)

\section{Improving Organizational Capacity}

\section{Tolerance for Failure}

- Universities should be more tolerant for failure. Initiatives for trying new methods should be established, in order to encourage innovation

- Regulations within institutions should be minimized to trigger innovation

- Different opinions should be tolerated to increase ideas that are generated

Vision and Transparency

- Information desks should be set up to enable tracking of recent trends. Policies, procedures and short/long term strategies should be clearly set and shared during enrolment and induction week

Diversity

- Cultural diversity should be improved, in both Faculties and the student body

- Student Unions, societies and clubs should be opened to foster a more international environment 


\section{References}

Baqir, M. N., \& Kathawala, Y. (2004). Ba for knowledge cities: a futuristic technology model. Journal of Knowledge Management, 8(5), 83-95. doi:10.1108/13673270410558828

Balogun, J., \& Hailey, V. H. (2008). Exploring Strategic Change Management. (3rd ed.) Harlow: Pearson Education Limited.

Boto, I., \& Biasca, R. (2012). Small Island Economies: from Vulnerabilities to Opportunties. Retrieved from http://www.cta.int/joomlatools-files/docman-

files/policy_papers/8_Building_resilience_in_small_island_economies.pdf

Cisco. (2015). Cisco Visual Networking Index: Forecast and Methodology, 2013-2018. Middle East (Vol. June). Retrieved from http://www.cisco.com/en/US/solutions/collateral/ns341/ns525/ns537/ns705/ns827/white_paper_c1 1-481360_ns827_Networking_Solutions_White_Paper.html

Cohen, W., \& Levinthal, D. (1990). Absorptive Capacity: A New Perspective on Learning and Innovation. Administrative Science Quarterly, 35(1), 128-152. doi:10.2307/2393553

Çalışma ve Sosyal Güvenlik Bakanlığı (2015). Yerel Iş̧ Gücünü Destekleme Projesi. Retrieved from https://csgb.gov.ct.tr/

Çavuşoğlu, B., \& Sağsan, M. (2011). National Knowledge Management Strategy for the TRNC: Recommendations for Small Island Economies. In Proceedings of the 12th European Conference on Knowledge Management: ECKM2011 (pp. 190-197). Academic Conferences Limited.

Drucker, F. P. (1977). People and Performance. London: Routledge Press.

Ergazakis, K., Metaxiotis, K., \& Psarras,J. (2004). Towards knowledge cities: conceptual analysis and success stories. Journal of Knowledge Management, 8(5), 5-15. doi:10.1108/13673270410558747

Ergazakis, K., Metaxiotis, K., Psarras, J., \& Askounis, D. (2006). A unified methodological approach for the development of knowledge cities. Journal of Knowledge Management, 10(5), 65-78. doi:10.1108/13673270610691189

Evers, H.-D., Gerke, S., \& Menkhoff, T. (2010). Knowledge clusters and knowledge hubs: designing epistemic landscapes for development. Journal of Knowledge Management, 14(5), 678-689. doi:10.1108/13673271011074836

Fill, C. (2011) Essentials of Marketing Communications. Harlow: Pearson Education Limited.

Franz, P. (2008). From university town to knowledge city: Strategies and regulatory hurdles in Germany. In T. Yigitcanlar, K. Velibeyoglu, \& S. Baum (Eds.), Knowledge-Based Urban Development: Planning and Applications in the Information Era (pp. 101-115). Hershey, PA: Information Science Reference. doi:10.4018/978-1-59904-720-1.ch006

Hilpert, U. (2006). Knowledge in the region: Development based on tradition, culture and change. European Planning Studies, 14(5), 581-599. doi:10.1080/09654310500500213

Joia, L. A., \& Lemos, B. (2010). Relevant factors for tacit knowledge transfer within organisations. Journal of Knowledge Management, 14(3), 410-427. doi:10.1108/13673271011050139

Junco, R., \& Clem, C. (2015). Predicting course outcomes with digital textbook usage data. The Internet and Higher Education, 27, 54-63. doi:10.1016/j.iheduc.2015.06.001

Kaya, T., \& Sağsan, M. (2015). The Impact of Tacit Knowledge Capacity on Social Media: An Empirical Research on Physicians in North Cyprus. 12 $2^{\text {th }}$ International Conference on Intellectual Capital, Knowledge Management and Organisaitonal Learning (pp. 133-141). Academic Conferences Limited. 
Kelly, U., McNicoll, I., \& White, J. (2015). The Impact of Universities on the UK Economy. Retrieved from http://www.universitiesuk.ac.uk/highereducation/Documents/2014/TheImpactOfUniversitiesOnT heUkEconomy.pdf

Mariano, S., \& Walter, C. (2015). The construct of absorptive capacity in knowledge management and intellectual capital research: Content and text analyses. Journal of Knowledge Management, 19(2), 372-400. doi:10.1108/JKM-08-2014-0342

Martinez-Fernandez, C., \& Sharpe, S. (2008). Intellectual Assets and Knowledge Vitality in Urban Regions: The Role of Universities. In T. Yigitcanlar, K. Velibeyoglu, \& S. Baum (Eds.), Creative Urban Regions: Harnessing Urban Technologies to Support Knowledge City Initiatives (pp. 48-64). Hershey, PA: Information Science Reference. doi:10.4018/978-1-59904-838-3.ch003

Mellor, R. B., Coulton, G., Chick, A., Bifulco, A., Mellor, N., \& Fisher, A. (2009). Entrepreneurship for Everyone. London: SAGE Publications Ltd.

Nonaka, I., Toyama, R., \& Konno, N. (2000). SECI, Ba and Leadership: A Unified Model of Dynamic Knowledge Creation. Long Range Planning, 33(1), 5-34. doi:10.1016/S0024-6301(99)00115-6

OECD. (1996). The Knowledge-Based Economy. Retrieved from http://www.oecd.org/sti/scitech/1913021.pdf

OECD. (2001). Cities and Regions in the New Learning Economy. Retrieved from http://www.oecdilibrary.org/education/cities-and-regions-in-the-new-learning-economy_9789264189713-en

Perry, B. (2008). Academic Knowledge and Urban Development: Theory, Policy, and Practice. In T. Yigitcanlar, K. Velibeyoglu, \& S. Baum (Eds.), Knowledge-Based Urban Development: Planning and Applications in the Information Era (pp. 21-41). Hershey, PA: Information Science Reference. doi:10.4018/978-1-59904-720-1.ch002

Sertoğlu, K., Besim, M., \& Tanova, C. (2015). Rekabet Edebilirlik Raporu 2014-2015. Retrieved from http://www.ktto.net/wp-content/uploads/2015/02/KTTO2014-2015.pdf

Thomson Reuters. (2015). Leaders of the global economy: Officers $\mathcal{E}$ directors alumni report. Retrieved from http://images.info.science.thomsonreuters.biz/Web/ThomsonReutersScience/\{7a0b9492-02c5-40909c1f-a3692e344aa5\}_SOI_Officers-and-Directors-Report_final4.pdf

United Nations. (2014). E-government survey 2014. Retrieved from https://publicadministration.un.org/egovkb/Portals/egovkb/Documents/un/2014-Survey/EGov_Complete_Survey-2014.pdf

Van Winden, W., Berg, Van Den, L., \& Pol, P. (2007). European Cities in the Knowledge Economy: Towards a Typology. Urban Studies, 44(3), 525-549. doi:10.1080/00420980601131886

Wang, C., \& Han, Y. (2011). Linking properties of knowledge with innovation performance: The moderate role of absorptive capacity. Journal of Knowledge Management, 15(5), 802-819. doi:10.1108/13673271111174339

Williams, L., Turner, N., \& Jones, A. (2008). Embedding Universities in Knowledge Cities: An Ideopolis and Knowledge Economy Programme Paper. London: The Work Foundation. Retrieved from http://hdl.voced.edu.au/10707/101249

Yeniduzen. (2015) Ekonomiye Ciddi Katkı. Retrieved from http://www.yeniduzen.com/Haberler/ozelhaber/ekonomiye-ciddi-katki/56458

Yigitcanlar, T. (2014). Expert Systems with Applications Position paper: Benchmarking the performance of global and emerging knowledge cities. Expert Systems With Applications, 41(12), 5549-5559. doi:10.1016/j.eswa.2014.03.032

Yigitcanlar, T., \& Velibeyoglu, K. (2008). Knowledge-Based Urban Development: The Local Economic Development Path of Brisbane, Australia. Local Economy, 23(3), 195-207. doi:10.1080/02690940802197358 
Yigitcanlar, T., \& Bulu, M. (2015). Dubaization of Istanbul: insights from the knowledge-based urban development journey of an emerging local economy. Environment and Planning A, 47(1), 89-107. doi:10.1068/a130209p

Yigitcanlar, T., \& Lönnqvist, A. (2013). Benchmarking knowledge-based urban development performance: Results from the international comparison of Helsinki. Cities, 31, 357-369. doi:10.1016/j.cities.2012.11.005

Yigitcanlar, T., O'Connor, K., \& Westerman, C. (2008). The making of knowledge cities: Melbourne's knowledge-based urban development experience. Cities, 25(2), 63-72. doi:10.1016/j.cities.2008.01.001

Yigitcanlar, T., Velibeyoglu, K., \& Martinez-Fernandez, C. (2008). Rising knowledge cities: The role of urban knowledge precincts. Journal of Knowledge Management, 12(5), 8-20. doi:10.1108/13673270810902902

YÖDAK. (2015). Universities. Retrieved from http://www.ncyodak.eu/ 